\title{
GEORAMA OF TRASH
}

\section{Design Earth}

\section{Rania Ghosn}

Assistant Professor

MIT School of Architecture + Planning, Cambridge, USA

\section{El Hadi Jazairy}

Assistant Professor of Architecture
University of Michigan, Ann Arbor, usA

In its material dimension, the land receives both the positive and negative externalities of human life. Trash, for instance, is a negative externality that also reaches the ground, but that is conveniently placed 'out of sight'. This project by Design Earth, however, proposes an opposite strategy: in a society that only reacts to fetishistic spectacularization, perhaps it is not unreasonable to think of projects that transform the trash into an architectural spectacle.

KEYWORDS · earth, environment, waste, garbage, theater

In the 'age of environment', the systems of trash have expanded to the planetary scale. Relegated to geographic space, waste practices continue to manage the disappearance of trash as matter-out-of place, in spaces beyond the city, and that to reaffirm the purity of what remains within. The mandate for 'clean' urbanism rests thus on the dissociation of the city from the environmental costs of urbanization, relegating responsibility for the inevitable 'dirty' waste products to political and geographic entities beyond city jurisdictions, or what is referred to as an "externality field" (Harvey, 1973:57-60). Because such spaces are beyond the city, their sites and forms remain beyond public and disciplinary scrutiny on how garbage could differently shape our geographies. The rise of environmentalist concerns invites us to account for all environmental externalities of the urban process, be they resource extraction, waste disposal, water management, nuclear testing, etc. Such worldviews bring to public consciousness the realization that there is no outside in which the unwanted consequences of our collective actions could be allowed to linger and disappear from view, that there was "no zone of reality in which we could casually rid ourselves of the consequence of human political, industrial, and economic life" (Latour, 2004:58). 

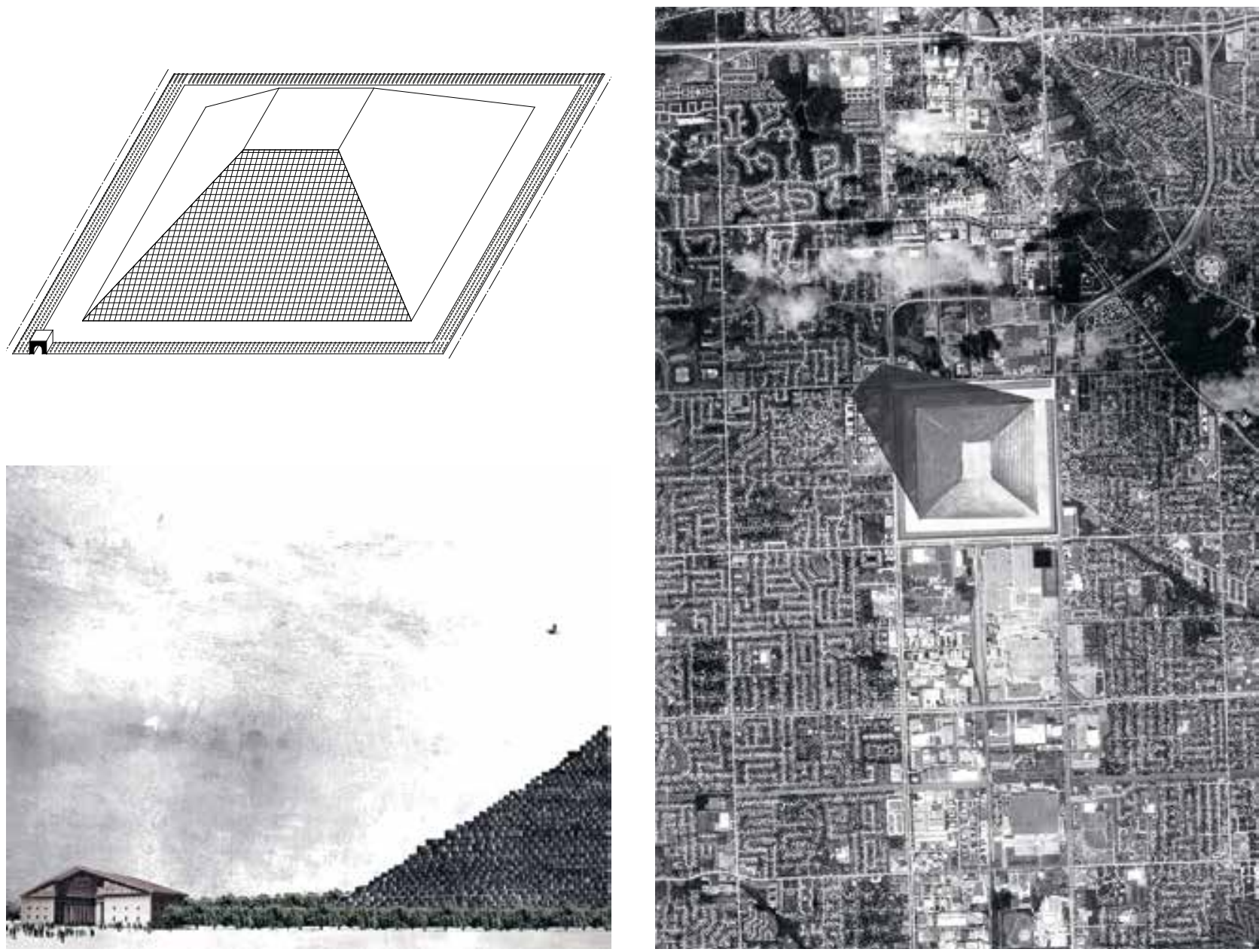

CAP

CAP formalizes the metrics of landfilling operations into a geographic monument.

Landfills have been evicted outside from city development. They are located in urban peripheries along major highway arteries, and buried beneath a swath of green carpet, hidden or 'naturalized' at the periphery. CAP gives monumental form to the components of landfill architecture - as both object and site. The project rationalizes the process of landfilling -cell construction, material stacking and truck circulationto give shape to a ziggurat of trash cells. Culminating the 20-mile automotive Mound Road Corridor, the project serves as a monument to de-centralizing and wasteful forces of Detroit's urbanization. By giving visible and monumental form to the landfill-here the weighing station in the foreground, and situating it within the city-CAP reclaims the infrastructure of waste as an object of civic pride, and disciplinary imaginary. 

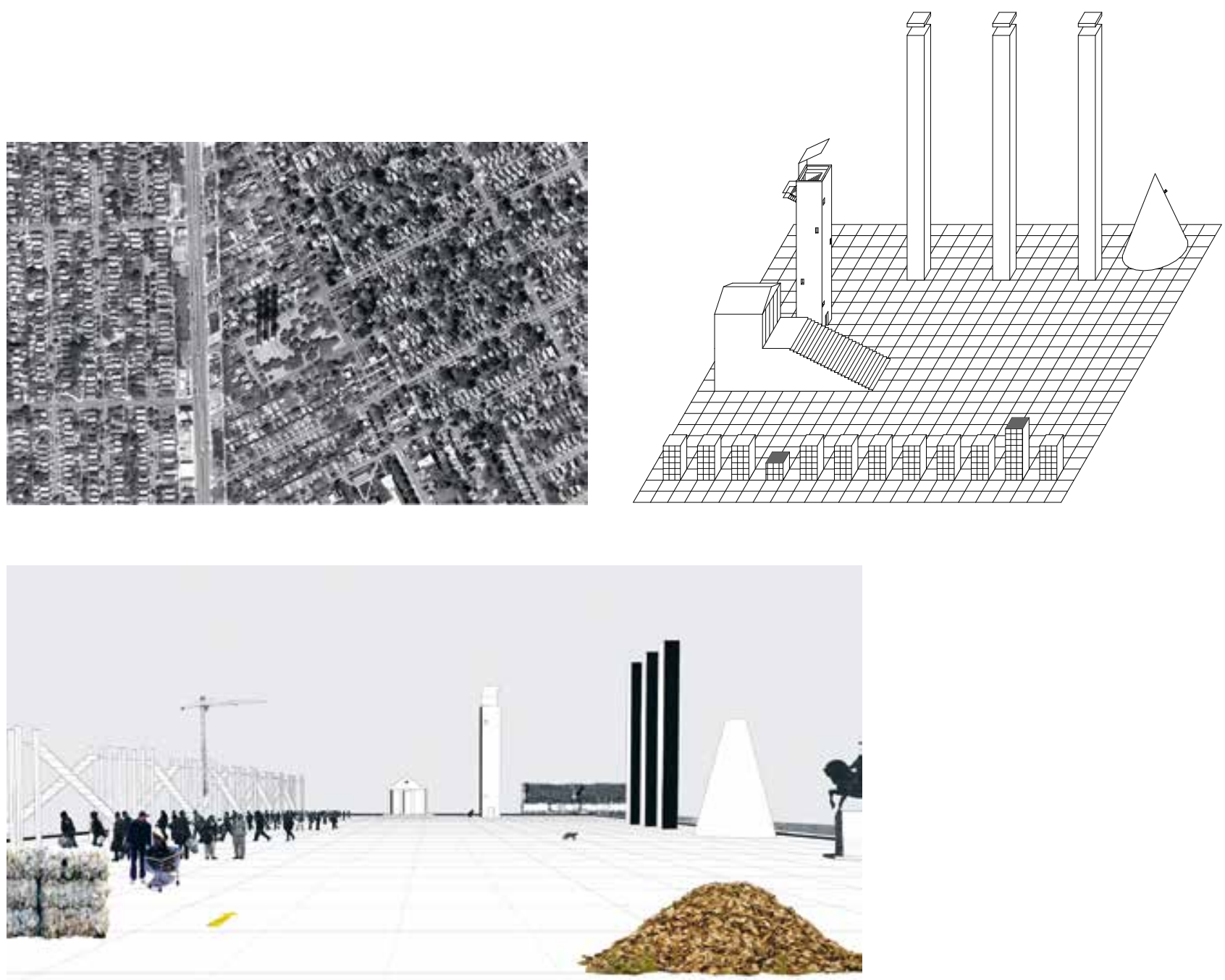

COLLECT localizes the surplus value of recycling out of the monopoly of vertically integrated corporations and within the scale of the neighborhood.

The revenue of recycling waste operators is gained from discerning objects that still hold value from those that are not. Various monopolizing entities in the waste management system have the possibility of extracting value, sometimes several times in the process, for example from charging the thrower for collection fees and then selling again to manufacturers. Can we imagine a process that reclaims the economic value of recycling for residents of the city, particularly at a moment when Detroit is defined by its loss of population, economic revenue and urban services? Can we deploy the economic value of recycling to mobilize social capital and social space in the shrinking city? COLLECT localizes the surplus value of recycling at the urban neighborhood unit. The project converts the Russell Woods neighborhood park into a ground for the collection, sorting, and redistribution of solid waste, thus transforming the neighborhood waste economy into the grounds of a collective project, away from the scavenger-consumer binaries. 

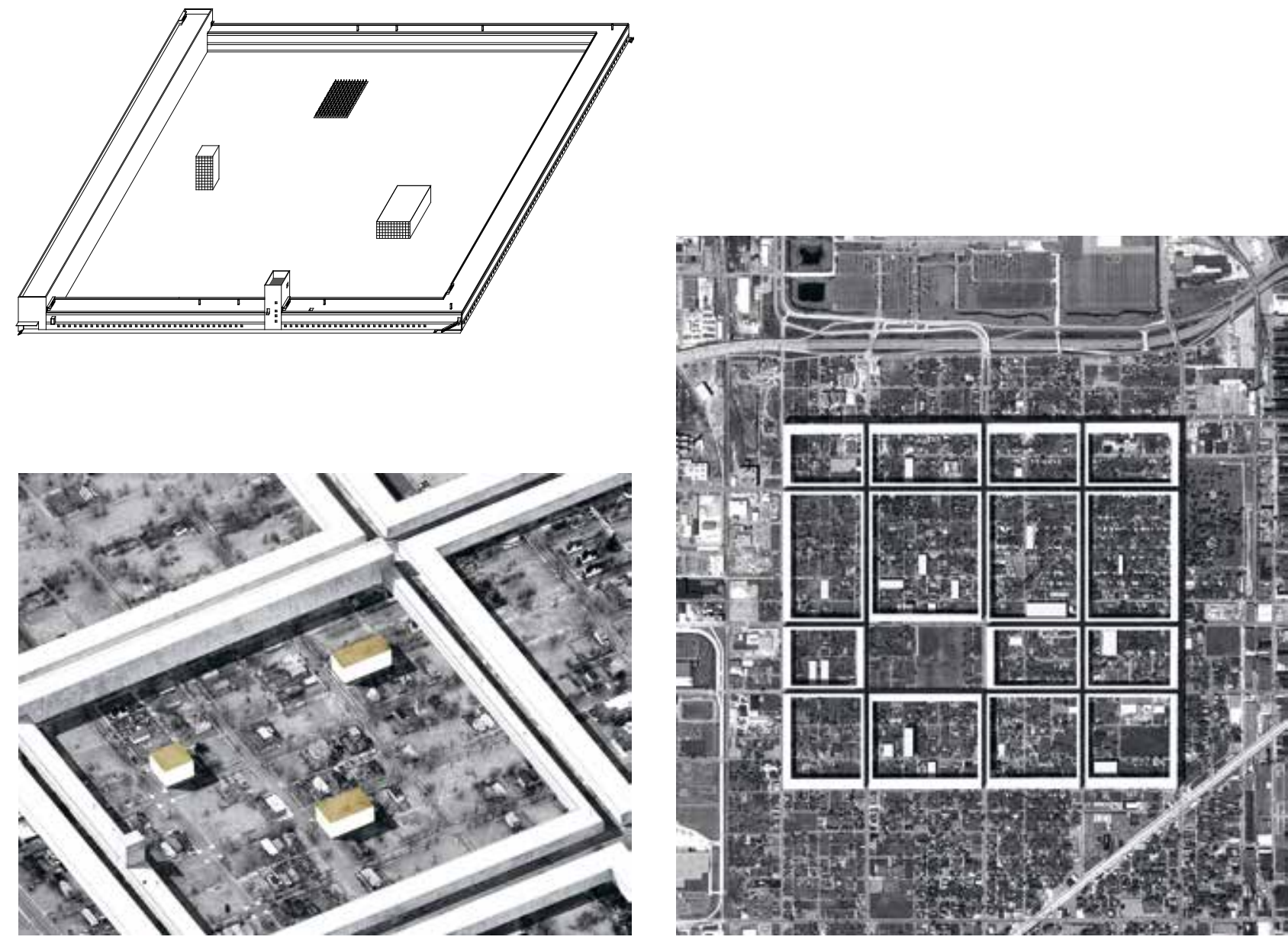

CONTAIN

CONTAIN integrates waste

management technologies into forms of building construction and urban interface at the scale of the block.

Trash is hauled over long distances, usually from affluent areas to less privileged one to displace the associated social costs. What happen if we limit the transit of garbage so that each community managed the waste it produced? What kinds of architecture would emerge if waste could not simply be carried away? Can waste management be rethought as a productive typology within urban environment? CONTAIN internalizes composting and burning within the courtyard of perimeter-building types. Detroit's shrinking economy has emptied out much of the city with some remaining cohesive enclaves. The project deploys trash management as a redevelopment strategy for the Poletown East neighborhood, which historically has been a location for grazing, orchards, and numerous immigrant communities. CONTAIN rebuilds Poletown from the waste it manages. Byproducts of low-tech composting constitute the soft surfaces of communal spaces within the block, such as lawns, fields, gardens. The bottom ash of high-tech burning is used as aggregate in the construction of hard surfaces for the perimeter housing blocks, such as pavement and concrete stones. Eventually, the project eliminates the distinction between waste and resources in the enclave-city. 

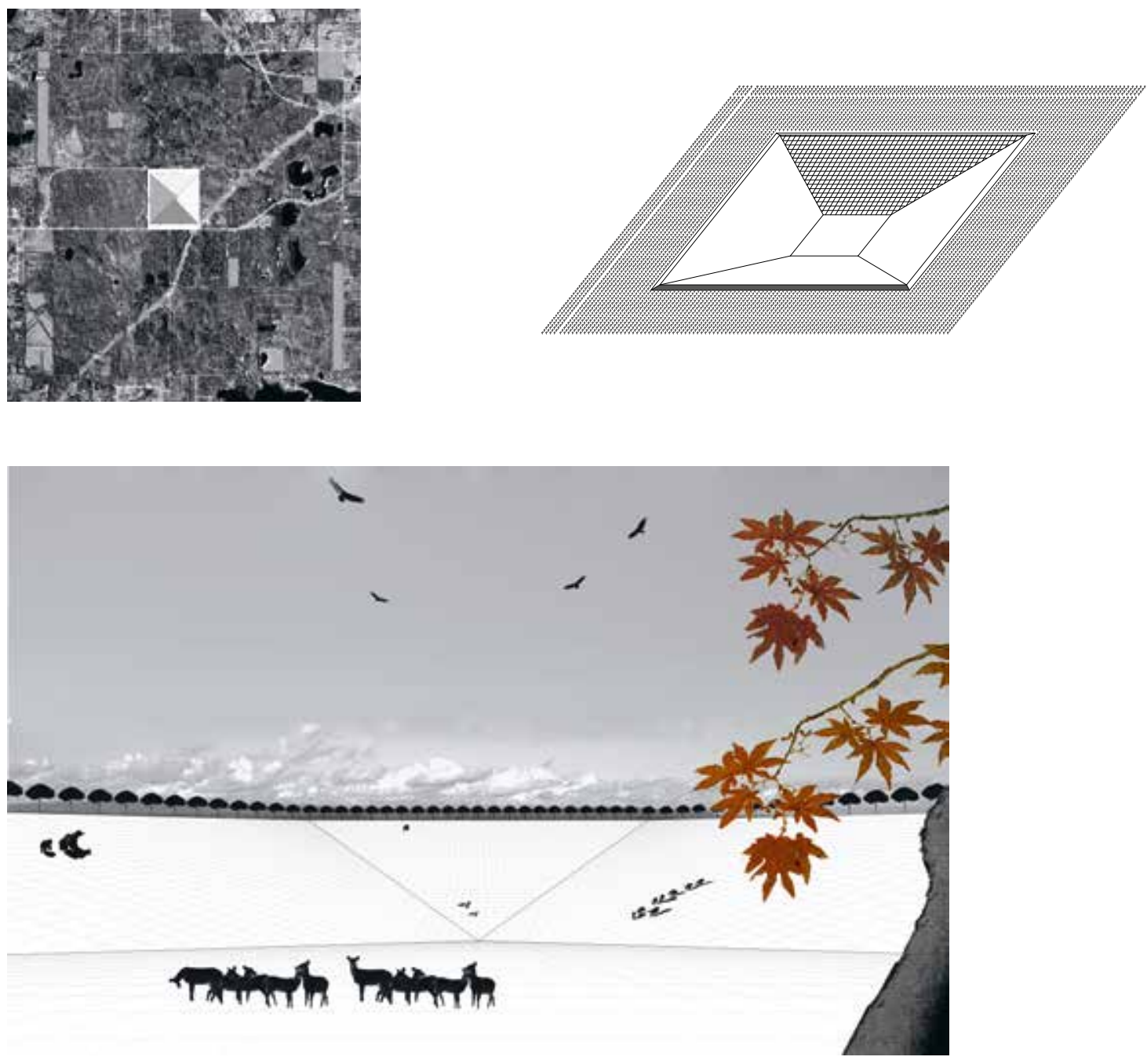

PRESERVE

PRESERVE curates ecologies by engineering the operation and lifecycle of a landfill.

Since the 1980s, landfills have been liners with a low permeability synthetic membrane -the same material used to make the plastic trash bag- to keep them from leaking fetid liquids into lakes, streams, and ground water. The life of the membrane extends, however, well beyond the time period for which states are required to maintain and monitor landfills after closures. Can we imagine alternative landfill ecologies other than those with an indeterminate lifespan? In a twist on the image and politics of nature, the project transforms a golf course within the Indian Springs Nature Preserve at the extents of Detroit's outer city into a renewable landfill. Within the site, the liner is replaced by decomposition strategies and remediation processes that allow trash to become part of the preserve's ecology. Such places liability on industrial and chemical operators before the toxicity of their waste before it arrives at the landfill. PRESERVE attracts bears and a multitude of species that can feed off such waste. A 1950 study found that most cities in the Detroit Metro region employed hogs for disposing of garbage either by contract with independent entrepreneurs or by operating their own piggeries. Such trash was subsequently compiled with soil to produce a fertile land. The project shifts the object of design from posttermination redevelopment strategies to the operating landfill itself as a politicalecological issue. 

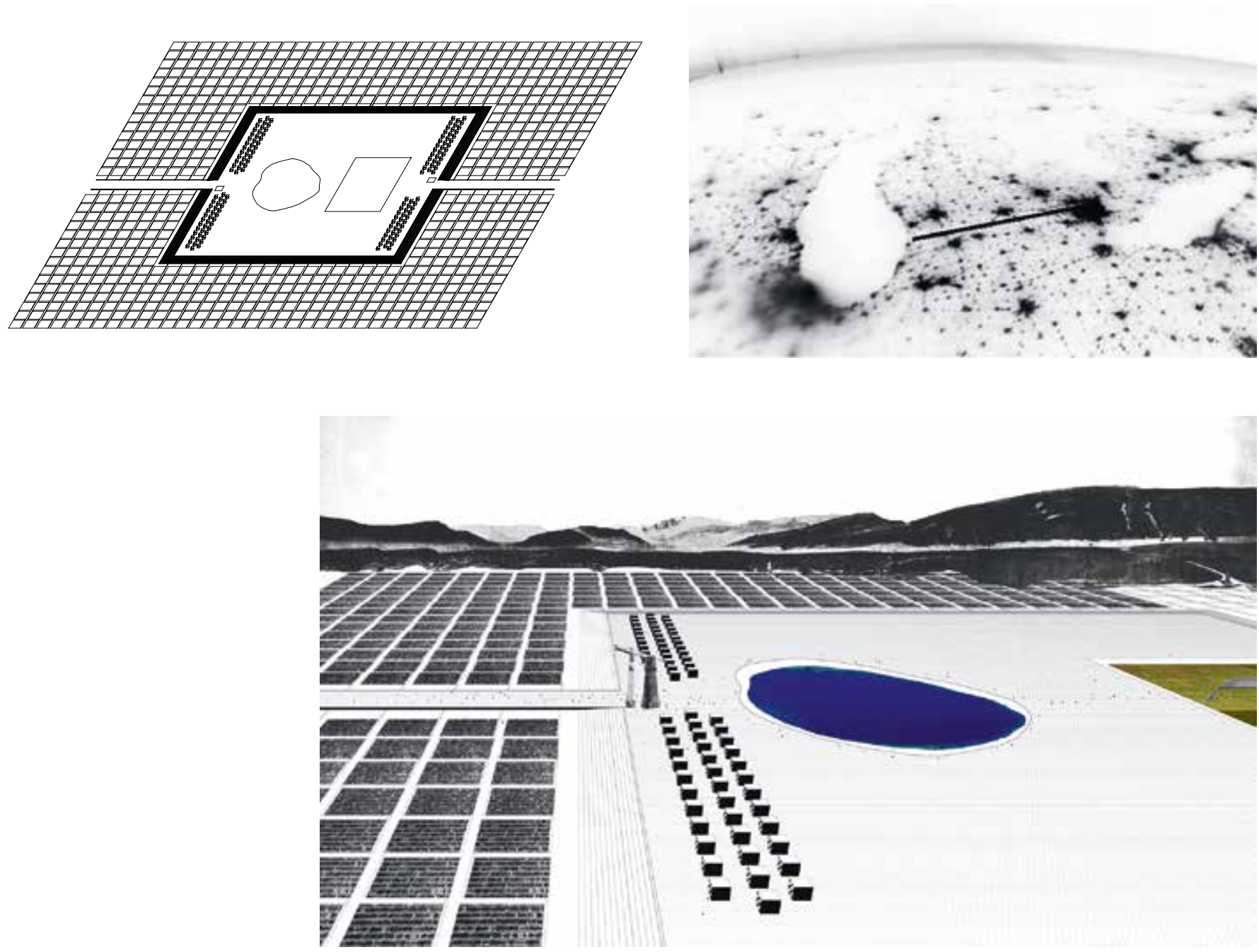

FORM plans for an economy of waste that integrates the large number of landfills in the urbanized corridor between Detroit and Lake Michigan all while capitalizing on their post-termination developmental potentials.

The State of Michigan capitalizes on its location at the geographic center of the Great Lakes Region, as well as its rock-bottom landfilling prices, low tipping fees, and environmental regulations far looser than those mandated in Canada. Over the next two decades, most of the landfills in Michigan's densest urban areas will have reached their maximum holding capacity. How can capped landfills offer a new model of urbanism in which the life of post-technological systems are incorporated at conception? FORM re-surveys a continuous waste management system along the urbanized corridor that begins in Detroit and extends westward along the Michigan baseline. The project engages geographical features (such as topographical changes, waterways, motorways, forests, towns, etc.) to form an archipelago of platforms within a continuous landfill stretching from Detroit to Lake Michigan. 


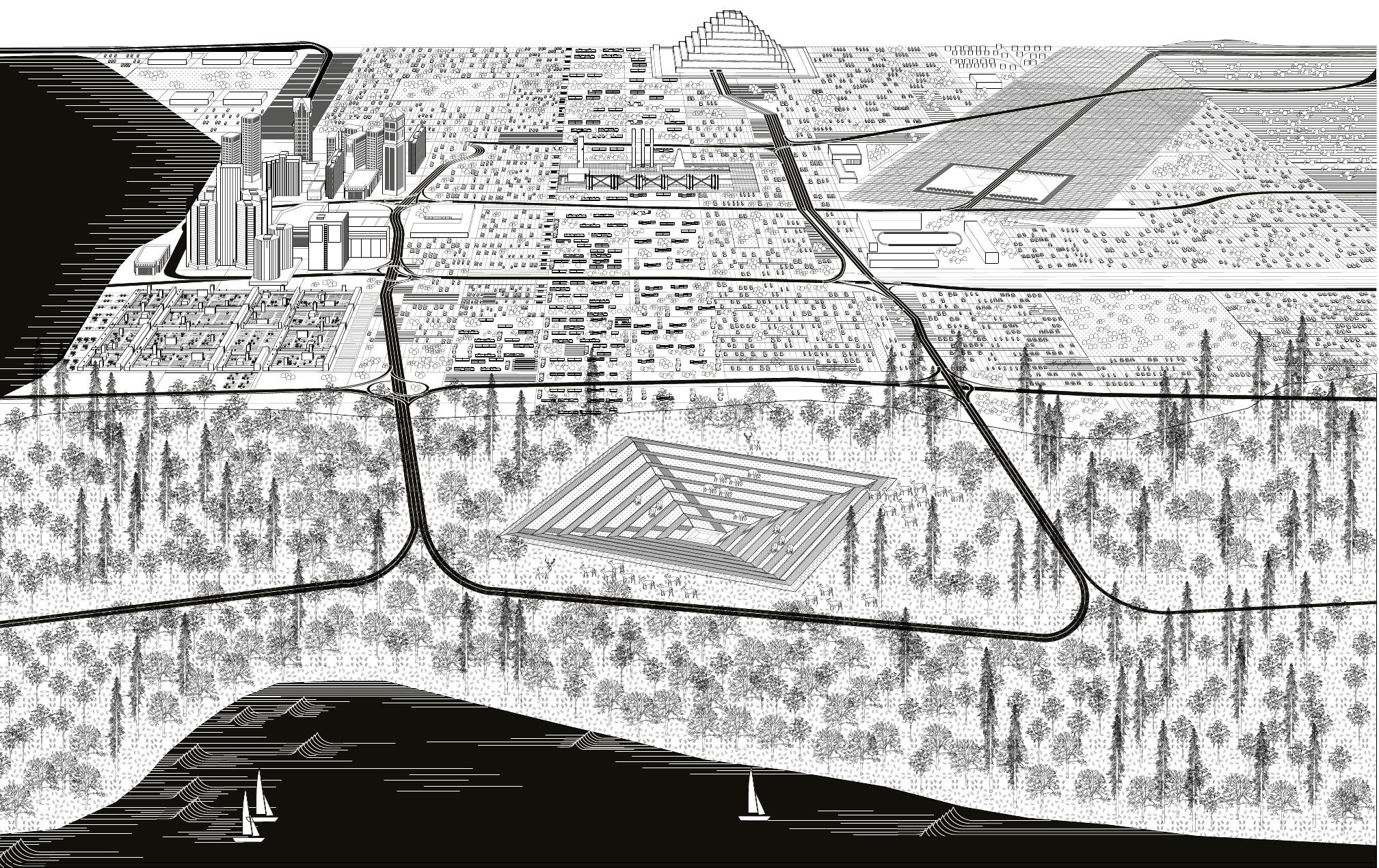

How can we reclaim the forms, technologies, economies and logistics of waste systems in the production of urbanism? If the externalization of trash has placed it outside of design's environmental agency, can the expansion of urban analysis and speculation to the geographic scale re-inscribe urban technological systems within disciplinary practices and imaginaries? DESIGN EARTH has engaged the expanded environmental imagination in a series of projects that make visible the geographies of waste systems and chart their material, political, and scalar attributes. These projects aspire to shift public debates from their focus on what Bruno Latour calls "matters-of-fact": that is, positivist solutions to 'garbage crises' which continue to insist that garbage must be kept out of sight as a factually repugnant entity (Latour, 2004:225-248). Instead, our practice seeks to draw attention to Latour's "matters-of-concern": arguments that accept the fact that trash creates problems that we must address, yet seeks alternative political and aesthetic propositions through the grounding of research and design in geographic specificities.

From the Greek geo (earth) and rama (spectacle), Georama of Trash, or an earthen spectacle of trash, makes public and spatial waste management practices. 
The large-scale drawing extends the representational research of the recently published Geographies of Trash (Ghosn \& Jazairy, 2015). The design-research publication charts geographies of trash in Detroit, Michigan across scales to bring to visibility the relations of technology, space and politics. It also proposes five situated yet generic architectural strategies -Cap, Collect, Contain, Preserve, and Form - that engage alternative imaginaries for landfilling, recycling, burning, re-using, dumping and valuing matter. Georama of Trash large-scale drawing stages these five speculative projects within one worldview. It places such undesired matter, of the trash bag and its associated logistics, economics, ecologies at the center of the 'Theater of the World.' Rather than a technological fix, the drawing immerses the spectator in the spaces of technological systems to stimulate the geographic imagination and engage a public conversation on trash and space. ARQ

- Georama of Trash will be exhibited at "The World in Our Eyes" (curated by Fabrizio Gallanti), at the Lisbon Architecture Triennale, 2016.

\footnotetext{
DESIGN EARTH

<office@design-earth.org>

Rania Ghosn and El Hadi Jazairy are partners of DESIGN EARTH. The practice engages the geographies of environmental systems to open aesthetic and political concerns for architecture and urbanism. DESIGN EARTH has been recognized with several awards, including Architectural League of New York Young Architects, the Jacques Rougerie Competition, and ACSA Faculty Design Award for their recently published Geographies of Trash (Actar, 2015). In 2016, their work is exhibited at MIT Keller Gallery, Venice Biennale, Lisbon Triennale and Oslo Architecture Triennale. Ghosn and Jazairy hold Doctor of Design degrees from Harvard Graduate School of Design. Ghosn is currently Assistant Professor at MIT School of Architecture + Planning (Cambridge, USA) and Jazairy is Assistant Professor of Architecture at the University of Michigan (Ann Arbor, USA).
}

\section{BIBLIOGRAFÍA / BIBLIOGRAPHY}

HARVEY, David. Social Justice and the City. London: Blackwell, I973. LAT Ou R, Bruno. Politics of Nature: How to Bring the Sciences into Democracy. Cambridge: Harvard University Press, 2004.

LATOU R, Bruno. «Why Has Critique Run Out of Steam?» Critical Inquiry 30.2 (2004): 225-248.

GHOS N, Rania; J A ZA I RY, El Hadi. Geographies of Trash. New York: Actar, 20I5. 